\title{
Zbirke starih japonskih razglednic v Republiki Sloveniji ${ }^{1}$
}

\section{Chikako SHIGEMORI BUČAR*}

\section{Izvleček}

V okviru raziskave "Vzhodnoazijske zbirke v Sloveniji" smo identificirali stare japonske razglednice v več ustanovah po Republiki Sloveniji. Za večino zbirk vemo imena posameznih zbiralcev in ozadje zbiranja. Ta prispevek predstavlja 160 razglednic, ki so bile med letoma 1899 in 1920 natisnjene na Japonskem, nekatere med njimi pa so v istem obdobju tudi uporabili. Fotografije na teh razglednicah lahko delimo na štiri kategorije: 1) pokrajina, pristanišča, mesta in turistične znamenitosti; 2) hiše, vrtovi, oblačila, pričeske in navade Japoncev; 3) posebni predmeti npr. lutke, ladje; 4) naravne nesreče.

Obdobje od konca 19. stoletja do leta 1920 lahko imenujemo "Doba razglednic", saj so razglednice $v$ tem času imele pomembno vlogo posredovanja informacij in novic iz daljnih krajev npr. $z$ Japonske in iz Vzhodne Azije.

Ključne besede: razglednica, Japonska, Meiji, Taishō, Avstro-Ogrska

\section{The Collections of Old Japanese Postcards in Republic of Slovenia}

\section{Abstract}

During our research "East Asian collections in Slovenia", old Japanese postcards were found in various institutions in today's Republic of Slovenia. For most of these postcards we know the names of individual collectors and their backgrounds.

This paper presents 160 picture postcards, produced in Japan and some of them used for correspondence between 1899 and 1920. The photos on these postcards may be categorized into the following four: 1) ports, cities and tourist sights; 2) houses, gardens, clothes, hairstyles and customs; 3) particular objects, e.g. dolls, ships; 4) natural disasters. The period from the end of 19th century to the 1920s may be called "the period of picture postcards", since postcards had the important role to convey information and news from far places such as Japan and East Asia.

Keywords: picture postcard, Japan, Meiji, Taishō, Austria-Hungary

1 Predhodna verzija tega članka je bila objavljena v monografiji v japonščini oktobra 2016 (glej Shigemori 2016). Po dodatnem raziskovanju in preverjanju podatkov v letu 2016/2017 objavljam rezultate dosedanje raziskave starih japonskih razglednic v Sloveniji.

* Chikako SHIGEMORI BUČAR, Izredna profesorica,

Oddelek za azijske študije, Univerza v Ljubljani, Slovenia.

chikako.bucar[at]guest.arnes.si 


\section{Uvod}

Leta 2013 smo na Oddelku za azijske študije na Filozofski fakulteti Univerze v Ljubljani s skupno pobudo sinologov, japonologov in koreanistov začeli $\mathrm{z}$ raziskavo "Vzhodnoazijske zbirke v Sloveniji - Identifikacija, kategorizacija in digitalizacija vzhodnoazijskih umetnostno-zgodovinskih zbirk in ostalega gradiva". Med raziskovanjem v letih 2014-16 sem bila pozorna na več zanimivih razglednic z Japonske, ki so ohranjene v različnih ustanovah po Sloveniji. Ta prispevek je poročilo o lokacijah in zgodovinskih okoliščinah posameznih zbirk japonskih razglednic v Sloveniji. V prispevku predstavljam vrste in značilnosti razglednic ter s slovenske (oz. srednjeevropske) perspektive analiziram "dobo razglednic" in funkcijo japonskih (in vzhodnoazijskih) razglednic v času med 1890 in 1920.

$\mathrm{V}$ drugem poglavju na kratko predstavljam zgodovinske in družbene okoliščine slovenskega in japonskega naroda $\mathrm{v}$ obravnavanem obdobju. $\mathrm{V}$ tretjem poglavju podrobno opisujem ustanove, $\mathrm{v}$ katerih sem našla japonske razglednice, in ozadje posameznih zbirk. Nato razpravljam o »dobi razglednic«, obdobju konca devetnajstega stoletja in prve polovice dvajsetega stoletja, in razčlenjujem funkcijo razglednic $\mathrm{v}$ tistem času. $\mathrm{Na}$ koncu predstavljam še načrt za nadaljne raziskave in naloge, zlasti v povezavi $\mathrm{z}$ razglednicami $\mathrm{v}$ zgodovinskem in sociološkem kontekstu.

\section{Zgodovinsko ozadje}

Tokrat sem analizirala 160 razglednic, ki so arhivirane v štirih različnih ustanovah po Republiki Sloveniji. Čas, ko so te razglednice nastale, ko so jih natisnili in uporabili, sega od devetdesetih let devetnajstega stoletja do dvajsetih let dvajsetega stoletja: to je čas, ko je slovenski narod živel v Avstro-Ogrske (do leta 1918) in nato postal del Kraljevine Srbov, Hrvatov in Slovencev, kasneje pa Kraljevine Jugoslavije.

V času Avstro-Ogrske je bil skupen javni jezik, na primer v poštnem sistemu, nemški. Po letu 1918 se je zaradi sobivanja z drugimi južnoslovanskimi narodi uporabljalo več sosednjih jezikov. Raba jezikov se vidi tudi na razglednicah, ki so jih dejansko uporabljali kot sredstvo komunikacije.

Na Japonskem pa sta bili to obdobji Meiji (do leta 1913) in Taishō (1913-1925). To je bil čas hitre industrializacije, večalo se je tudi število tujih obiskovalcev. V tem času sta bila del Japonske tudi Tajvan in Koreja. Po mirovni pogodbi v Shimonosekiju po prvi kitajsko-japonski vojni so bili Japonski prepuščeni polotok Laodong, Tajvan, in otočje Penghu, leta 1910 pa je bila aneksirana še Koreja. Vsa ta območja so bila pod nadzorom Japonske do konca druge svetovne vojne. $\mathrm{V}$ 
okviru te raziskave sem našla tudi veliko razglednic, ki sicer predstavljajo pokrajino, navade in znamenite kraje na Tajvanu in v Koreji, ki pa so jih oblikovali in natisnili japonski založniki, zato so napisi oz. razlage slik v japonščini.

V dosedanji raziskavi sem v Piranu našla dvajset in v Celju šestnajst razglednic na osnovi fotografij, posnetih v današnji Koreji, na današnjem Kitajskem in na Tajvanu. V primeru današnje Kitajske so to pristanišče Lushun (Ryojun / Port Arthur) in bojišče rusko-japonske vojne v Mandžurji. Ohranjene so tudi razglednice, ki prikazujejo navade in kraje iz Tajvana iz istega časa. Večina teh razglednic $\mathrm{v}$ ta prispevek še ni vključena in čaka na obdelavo, vemo pa, da so bile izdelane v tem obdobju v istem okviru kot druge japonske razglednice.

\section{Ustanove in zbirke}

VTabeli 1 so imena ustanov, v katerih sem našla stare razglednice, ki predstavljajo japonske turistične kraje, pokrajino, ljudi in navade. Zraven vsake ustanove navajam še ime zbiralca, če je znano, število razglednic in čas nastanka oz. uporabe teh razglednic. Nekateri od zbiralcev, ki so bili sami na Japonskem, so prinesli s seboj ne samo razglednice, temveč tudi fotografije, knjige, umetnostne slike in pohištvo, oblačila ter drobne spominke, ki jih ravno tako hranijo te ustanove. V tem prispevku predstavljam samo razglednice.

\begin{tabular}{|c|c|c|c|}
\hline Ustanova & Zbirka (Ime zbiralca) & Število & Čas uporabe \\
\hline NUK, Ljubljana & $?$ & 13 & 1899 \\
\hline Biblioteka SAZU, Ljubljana & Ivan Jager & 3 & 1902 \\
\hline \multirow{3}{*}{$\begin{array}{c}\text { Pomorski muzej Sergeja } \\
\text { Mašere, Piran }\end{array}$} & Ivan Koršič & 28 & $1904-1914$ \\
\cline { 2 - 4 } & Viktor Kristan & 61 & $1908-1909$ \\
\cline { 2 - 4 } & Anton Blaznik & 16 & $1905-1913$ \\
\cline { 2 - 4 } & Matevž Štibil & 3 & 1912 \\
\hline Regionalni muzej v Celju & Alma Karlin & 36 & $1922-1923$ \\
\hline & skupaj & 160 & \\
\hline
\end{tabular}

Tabela 1: Ustanove, zbirke in cas uporabe japonskih razglednic

Število in vrste razglednic, ki so navedene v tabeli, razkrivajo precejšnje zanimanje Slovencev za Japonsko v obdobju od konca devetnajstega stoletja naprej. Kot sem omenila, je slovenski narod v tem času doživljal velike politične in družbene 
spremembe. S stališča vsakodnevnega življenja takratnih Slovencev je bil geografsko zelo oddaljeni "Daljni vzhod" (Japonska in Vzhodna Azija) zunaj dosega in obiskali so ga lahko samo določeni privilegirani ljudje. Razglednice, ki jih obravnavam na tem mestu, so bile verjetno dragocen vir informacije za manj privilegirane Slovence. Del radovednosti in občutkov Slovencev lahko razberemo tudi v rokopisnem besedilu na razglednicah, ki so bile dejansko poslane.

$\mathrm{V}$ nadaljevanju sledi opis ustanov, predstavitev posameznih zbiralcev in ozadje posameznih zbirk, kolikor je znano. Analiziram tudi značilnosti razglednic.

\section{NUK, Ljubljana}

Najstarejše japonske razglednice, za katere vemo, da so ohranjene v današnji Republiki Sloveniji, so arhivirane v Narodni in univerzitetni knjižnici v Ljubljani. Enota za kartografsko in slikovno zbirko NUK-a hrani stare razglednice in fotografije $\mathrm{z}$ vsega sveta, ki predstavljajo zanimive pokrajine, ljudi in navade različnih krajev, razvrščene po današnjih imenih držav. V kategoriji "Japonska” je danes shranjenih štirinajst razglednic, med katerimi je tudi ena razglednica $z$ zemljevidom Japonske in Japonskega morja (napisi v nemščini razlagajo pomorsko bitko med rusko-japonsko vojno). Ker je očitno, da je bila ta razglednica natisnjena v Evropi, je ne upoštevam kot japonsko, zato kot število ohranjenih japonskih razglednic v NUK-u navajam trinajst. Med trinajstimi razglednicami so bile štiri leta 1899 dejansko poslane. Vse štiri so bile s podpisom "Pepon" poslane z Japonske, natančno iz Nagasakija, Jokohame in Kobeja, trem različnim naslovnikom v današnjem Knežaku in Rakeku v Sloveniji. Besedilo je v nemščini in razberemo lahko tudi sorodsvene vezi nekaterih ljudi, ki so si dopisovali. V Tabeli 2 za vse štiri razglednice, poslane $z$ Japonske, navajam, datum korespondence, vsebino fotografije, naslovnika idr. Na drugih devetih razglednicah ne vidimo sledi uporabe, glede na slog in način tiskanja pa se vidi, da so nastale v istem času. Najbrž je vse kupil "Pepon", ko je bil na Japonskem, in je uporabil prej omenjene štiri razglednice, druge pa prinesel nazaj v Slovenijo ali pa jih podaril enemu od naslovnikov.

V Enoti za kartografsko in slikovno zbirko v NUK-u so mi povedali, da ni nobene informacije o tem, po kateri poti so te razglednice prišle $\mathrm{v}$ arhiv. ${ }^{2}$

2 Naziv Univerzitetna knjižnica v Ljubljani si je knjižnica pridobila šele leta 1938. Pred tem je bila najprej jezuitska in licejska knjižnica, sredi devetnasjtega stoletja pa Deželna študijska knjižnica znotraj Avstro-Ogrske. Po koncu prve svetovne vojne je leta 1919 s preimenovanjem v Državno študijsko knjižnico postala osrednja knjižnica za vso Slovenijo. Ob ustanovitvi prve slovenske univerze v Ljubljani leta 1919 je knjižnica prevzela še funkcije in naloge centralne univerzitetne knjižnice. Vse do izgradnje Plečnikove stavbe leta 1941 so bile knjige in gradiva ohranjeni v 18 različnih čitalnicah. (Zgodovina NUK) 


\begin{tabular}{|l|l|l|l|l|}
\hline $\begin{array}{l}\text { Pošta na } \\
\text { Japonskem }\end{array}$ & Datum & Vsebina fotografije & Naslovnik & Opombe \\
\hline Nagasaki & $\begin{array}{l}15.6 . \\
1899\end{array}$ & $\begin{array}{l}\text { Mati s pahljačo v } \\
\text { roki gleda na spečega } \\
\text { otroka (fotografija } \\
\text { je približno 1/5 cele } \\
\text { površine) }\end{array}$ & $\begin{array}{l}\text { Oberförster Scholl- } \\
\text { mayer, Mašun(?) Post } \\
\text { Grafenbrunn b. St. Peter } \\
\text { Krain }\end{array}$ & $\begin{array}{l}\text { danes Kne- } \\
\text { žak, } \\
\text { tikanje }\end{array}$ \\
\hline Nagasaki & $\begin{array}{l}15.6 . \\
1899\end{array}$ & $\begin{array}{l}\text { Reka in most (Brez } \\
\text { pripisa. Fotografija } \\
\text { je približno 1/2 cele } \\
\text { površne.) }\end{array}$ & $\begin{array}{l}\text { Wilhelmina Gräfin Li- } \\
\text { chtenberg in Hallerstein } \\
\text { Post Altenmarkt Rakek } \\
\text { Krain }\end{array}$ & $\begin{array}{l}\text { danes Ra- } \\
\text { kek, } \\
\text { vikanje }\end{array}$ \\
\hline Jokohama & $\begin{array}{l}6.7 . \\
1899\end{array}$ & $\begin{array}{l}\text { Hakone Yumoto, slap } \\
\text { Tamadare no taki } \\
\text { (fotografija je 1/2 } \\
\text { površine) }\end{array}$ & $\begin{array}{l}\text { Wilhelmina Gräfin Li- } \\
\text { chtenberg in Hallerstein } \\
\text { Post Altenmarkt Rakek } \\
\text { Krain }\end{array}$ & $\begin{array}{l}\text { danes Ra- } \\
\text { kek, } \\
\text { vikanje }\end{array}$ \\
\hline Kobe & $\begin{array}{l}25.7 . \\
1899\end{array}$ & $\begin{array}{l}\text { Kobe Oriental Hotel, } \\
\text { Irisov vrt v Horikiriju } \\
\text { (Tokio), gora Fuji s } \\
\text { snegom (tri različne } \\
\text { scene krasi približno } \\
\text { 2/3 površne) }\end{array}$ & $\begin{array}{l}\text { frau Marie Schollmayer } \\
\text { Mašun pri Grafenbrunn } \\
\text { bei St. Peter Krain }\end{array}$ & $\begin{array}{l}\text { piše (njen) } \\
\text { brat Pepon }\end{array}$ \\
\hline
\end{tabular}

Tabela 2: Podatki o štirih uporabljenih razglednicah v NUK-u
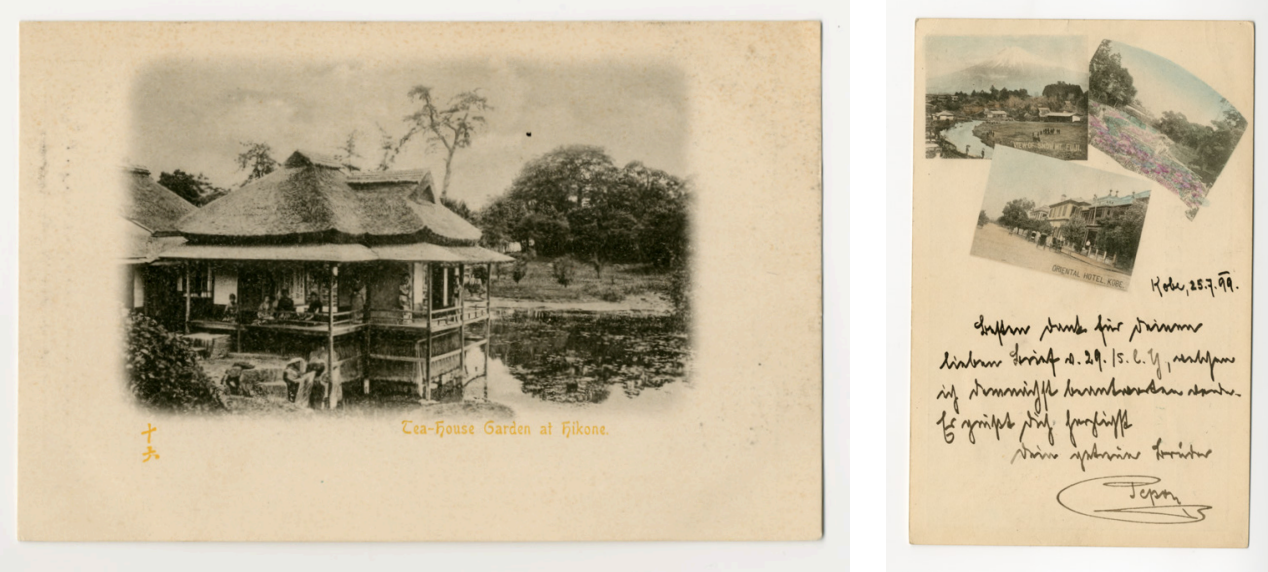

Slika 1: Čajna hiša v Hikoneju [levo] in Kobe Oriental Hotel, irisov vrt v Horikiriju in gora Fuji s snegom [desno] (NUK) 
Glede na datume na štirih razglednicah domnevamo, da je pisec z vzdevkom Pepon potoval na križarki SMS Kaiserin Elizabeth. ${ }^{3}$ Naslovniki so bili višji gozdar ${ }^{4}$ in njegova žena ter grofica ${ }^{5}$ na Notranjskem, v Knežaku oz. na Rakeku. Po besedilu vidimo, da sta pisec in gozdarjeva žena brat in sestra, grofico v Rakeku je pisec vikal.

Vse japonske razglednice v NUK-u predstavljajo takratne japonske pokrajine in ljudi. V primerjavi $z$ novejšimi razglednicami, ki so bile narejene $v$ dvajsetem stoletju, je razlika $v$ tem, da je na sprednji strani s fotografijo vedno nekaj prostora pod fotografijo ali pa na njeni levi oz. desni strani, kamor so uporabniki lahko pisali besedilo. Razlaga fotografije je navadno v angleščini natisnjena takoj pod fotografijo ali na fotografiji. To kaže, da so bile te razglednice narejene za tuje obiskovalce, v večini primerov iz zahodnih držav. Fotografije na teh razglednicah prikazujejo veliko šintoistično svetišče Kasuga v Nari (Kasuga taisha), vrata Yōmei (Yōmeimon) in zgradbo za Mahāvairocano (Dainichidō) v Nikkōju, Ōgiya v Ōjiju, Tokio, čajno hišo v Hikoneju, prikaz japonskega čajnega obreda idr. Vse to so rjavkaste črno-bele fotografije, druge fotografije pa so črno-bele fotografije $z$ barvami, ki so bile nanešene ročno. Motivi na barvnih razglednicah so pogled na goro Fudži iz vasi Ōmiya, gora Fudži in slapovi Shiraito, sprevod nosilnic čez Hakone in štirje zgoraj opisani (v Tabeli 2).

\section{Biblioteka SAZU, Ljubljana: Jagrova zbirka}

Nekoliko novejše razglednice iz Japonske najdemo v Biblioteki SAZU v Ljubljani, med razglednicami v zapuščini Ivana Jagra. Ivan oz. John Jager se je rodil v bližini Bistre pri Vrhniki leta 1871 in po končanem visokošolskem študiju na Visoki tehniški šoli na Dunaju ga je avstrijska vlada poslala na Kitajsko da bi obnovil v boksarski vstaji leta 1901 porušeno avstrijsko poslaništvo v Pekingu. ${ }^{6}$ Med bivanjem na Kitajskem je Jager spoznal vzhodno azijsko kulturo in se začel zanimati ter zbirati oblačila in manjše kose kitajske svile, japonske lesoreze, orožje in branike mečev tsuba itd. Leta 1902 se je preselil v ZDA in je živel v Minneapolisu, kjer je bil aktiven kot arhitekt in strokovnjak za urbanizem itd. V njegovi zbirki je tudi veliko knjig o filozofiji, zgodovini, arhitekturi, antropologiji in jezikoslovju. Jagrova zbirka, ki je zdaj ohranjena v Biblioteki SAZU, je bila donacija Jagrove vdove (Pajsar 2007) in med njimi so tri razglednice $z$ Japonske. Dve sta bili uporabljeni in popisani v slovenščini kot korespondenca med Ivanom Jagrom in takratno zaročenko Selmo, ki je živela na

3 Zahvaljujem se za pomoč ge. Nani Miyata, Österr. Akademie der Wissenschaften, Wien, Institut für Neuzeit- u. Zeitgeschichts-forschung.

4 Oberförster

5 Gräfin

6 O Ivanu (Johnu) Jagru glej Rothaus 2013 in Čeplak Mencin 2012, 140-1. 
Dunaju. Datuma v besedilu sta 29. december 1901 in 10. januar 1902, po poštnem žigu pa vidimo, da sta obe prispeli na Dunaj januarja 1902.

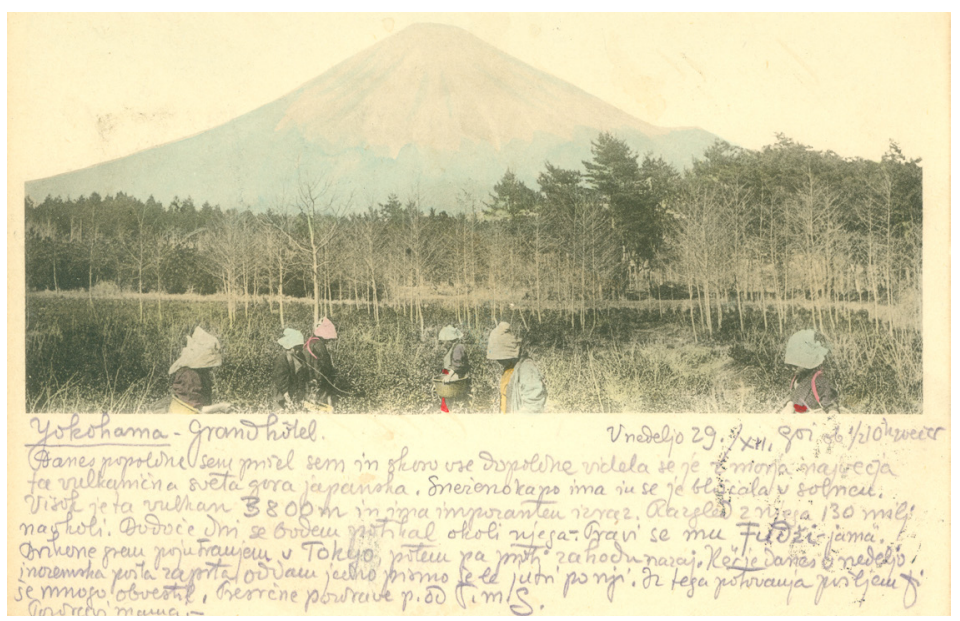

Slika 2: Trganje čajnib listov (Biblioteka SAZU)

Sestava oz. oblika teh razglednic je podobna tistim v NUK-u, ki sem jih predstavila v prejšnjem poglavju. Del fotografije na sprednji strani je manjši od celotne površine razglednice, pokriva od polovice do dveh tretjin razglednice, pod fotografijo ali zraven nje je še prostor za besedilo. Fotografije so črno-bele s kasnejšim ročnim barvanjem. Motivi so svetišče Nankō pri Kōbeju, trganje čajnih listov z ozadjem gore Fudži, kamnit most, vsi brez razlag. Tisk na hrbtni strani (za naslove idr.) je v istem formatu kot razglednice v NUK-u, npr. napis "razglednica Univerzalne poštne unije” 萬国郵便聯合端書 (Bankoku yūbin rengō hagaki) je napisan po japonsko $\mathrm{z}$ desne proti levi.

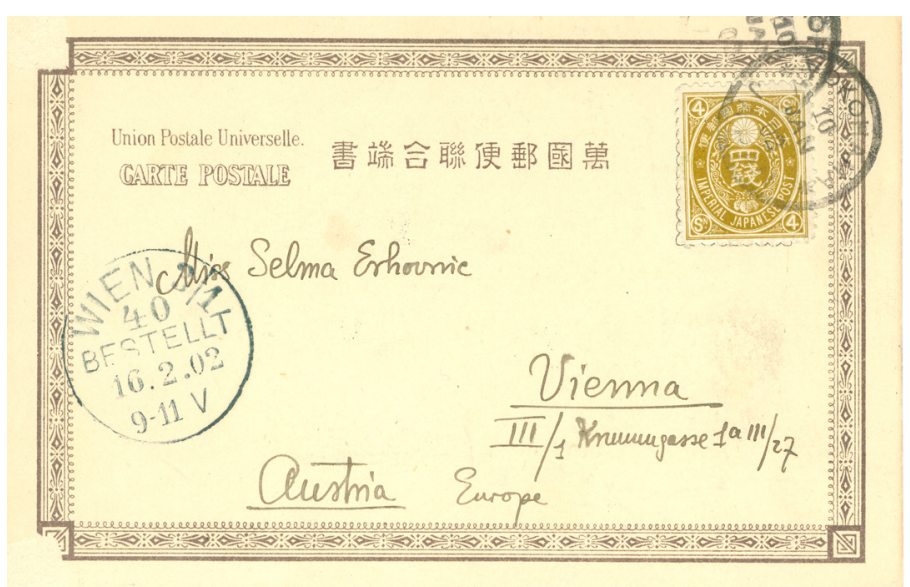

Slika 3: Hrbtna stran razglednice Trganje čajnih listov (Biblioteka SAZU) 


\section{Pomorski muzej Sergeja Mašere v Piranu}

Pomorski muzej Serjega Mašere v Piranu je zanimiv, ker se specializira za zgodovino pomorskih dejavnosti $\mathrm{v}$ tem kraju in njegovi okolici, najprej $\mathrm{v}$ avstrijskem in nato avstro-ogrskem času, kasneje pa v Sloveniji v okviru Jugoslavije. Hrani tudi gradivo o pomorstvu v povojni Jugoslaviji (Marinac 2005). Ima več zbirk in število razglednic $v$ posameznih zbirkah je tudi večje. Veliko je tudi razglednic in fotografij, ki prikazujejo življenje pomorščakov v času, ko se je politična ureditev spreminjala. Kot drugo značilnost zbirk v tem muzeju lahko omenim, da so razglednice in/ali fotografije zbrane $\mathrm{v}$ albumih.

Osrednje pristanišče avstro-ogrske mornarice je bilo na začetku v Benetkah, nato v Trstu, po letu 1856 pa v Pulju. Na začetku dvajsetega stoletja je bila avstro-ogrska mornarica ena najmočnejših na svetu, leta 1914 je bilo v njej na primer skoraj dvajset tisoč vojakov. Narodnostno je bila zelo pisana: v njej so sodelovali Hrvati, Madžari, Avstrijci, Italjani, Slovenci, Poljaki, Čehi, Slovaki idr. (povzeto po letaku Muzeja Sergeja Mašere). Zbirke, ki sem jih našla med tokratno raziskavo, so nastale v času Avstro-Ogrske, zato so poštni naslovi ter besedila na razglednicah v različnih jezikih, npr. slovenskem, hrvaškem, nemškem, italjanskem.

\section{Koršičeva zbirka}

Najstarejša zbirka japonskih razglednic, ki se hrani v Pomorskem muzeju v Piranu, je album Ivana Koršiča. Ivan Koršič se je rodil 1870 v Solkanu, postal je katoliški duhovnik in je služboval pri avstro-ogrski mornarici kot mornariški superior (vojaški škof). Koršič sam pa ni nikoli potoval v Vzhodno Azijo, vendar so mu številni mornarji pošiljali razglednice $z$ vsega sveta. Skupaj naj bi imel osem albumov, v katerih je ohranjenih 1871 fotografij in razglednic (Čeplak 2012, 98). Med njimi sem našla osemindvajset razglednic, ki prikazujejo japonske pokrajine in navade. Tri razglednice so črno-bele fotografije, druge pa, kakor sem ugotovila tudi pri drugih zbirkah, črno-bele fotografije $\mathrm{z}$ dodatnim obarvanjem.

Motivi na teh razglednicah so: pristanišča (Nagasaki, Kōbe, Jokohama), prizori iz mesta Tokio, stara svetišča in templji. Na 16 razglednicah vidimo pripis pod fotografijo (naslov fotografije) v japonščini in angleščini (japonščina je napisana po takratnem pravopisnem pravilu $z$ desne proti levi). Med razglednicami brez pripisa so takšne, ki prikazujejo japonske navade in običaje: rikše; dekle, ki je oblečeno v kimono in igra na piščal; dekleti, ki plešeta v sobi; dekleta na japonskem vrtu; ženske na vrtu pod glicinijo idr. Na razglednici, ki prikazuje japonsko mizarsko delo s tremi mizarji oz. tesarji, je napis »CARPENTERS«v angleščini. 


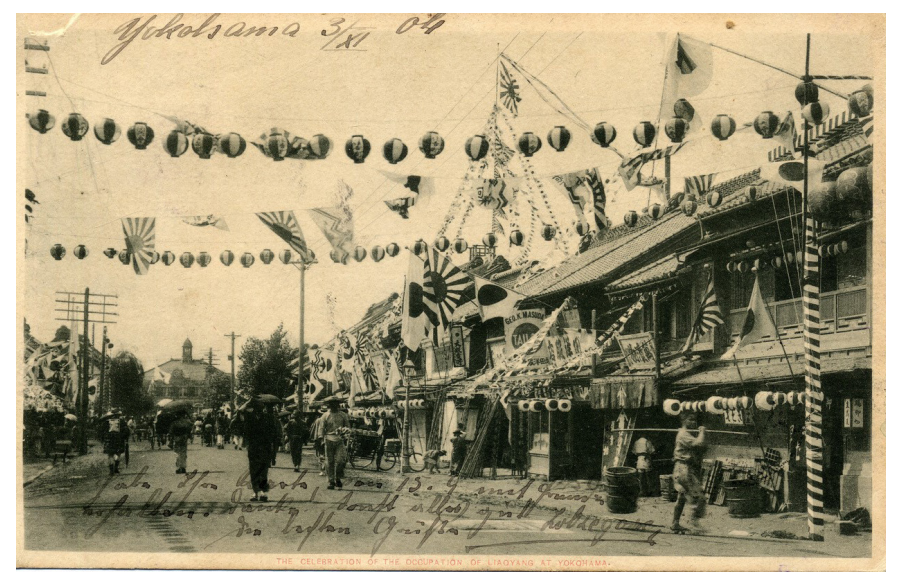

Slika 4: Yokohama (Koršičeva zbirka, Pomorski muzej v Piranu)

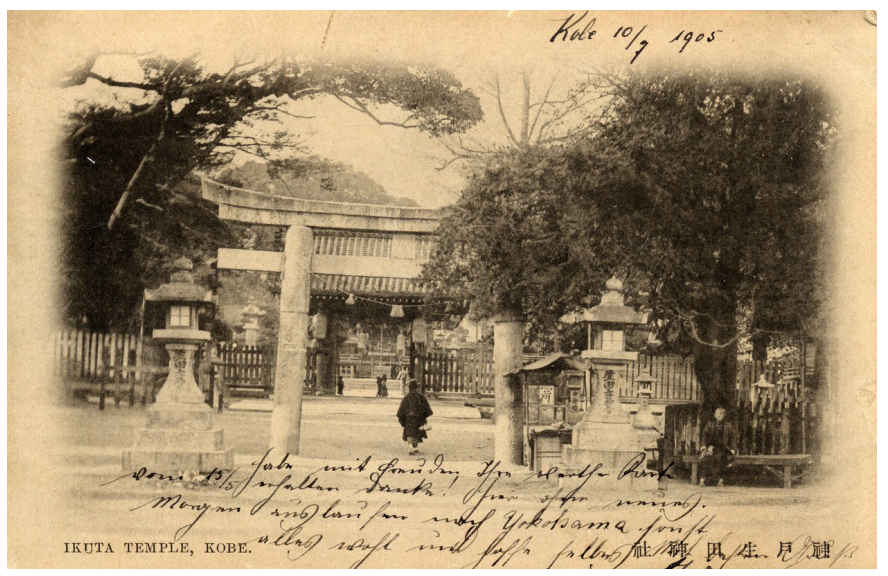

Slika 5: Ikuta tempelj, Kobe (Koršičeva zbirka, Pomorski muzej v Piranu)

$\mathrm{Na}$ treh od osemindvajset razglednic je na sprednji strani približno petina površine prostora za korespondenco. $\mathrm{Na}$ vseh drugih je fotografija po celi površini: ker so vse razglednice $\mathrm{v}$ tem albumu nalepljene, ne moremo pogledati na hrbtno stran. Po raziskavi Urakawe (2008 East Asia Image Collection Blog: 133) vemo, da so se japonske razglednice preoblikovale marca 1907 in od takrat je del hrbtne strani namenjen besedilu korespondence. To se pravi, da so bile tiste razglednice v Koršičevi zbirki, na katerih je fotografija po celotni površini sprednje strani, verjetno natisnjene po aprilu 1907. Vemo tudi, da je Koršič zbiral razglednice in fotografije med letoma 1904 in 1914. 


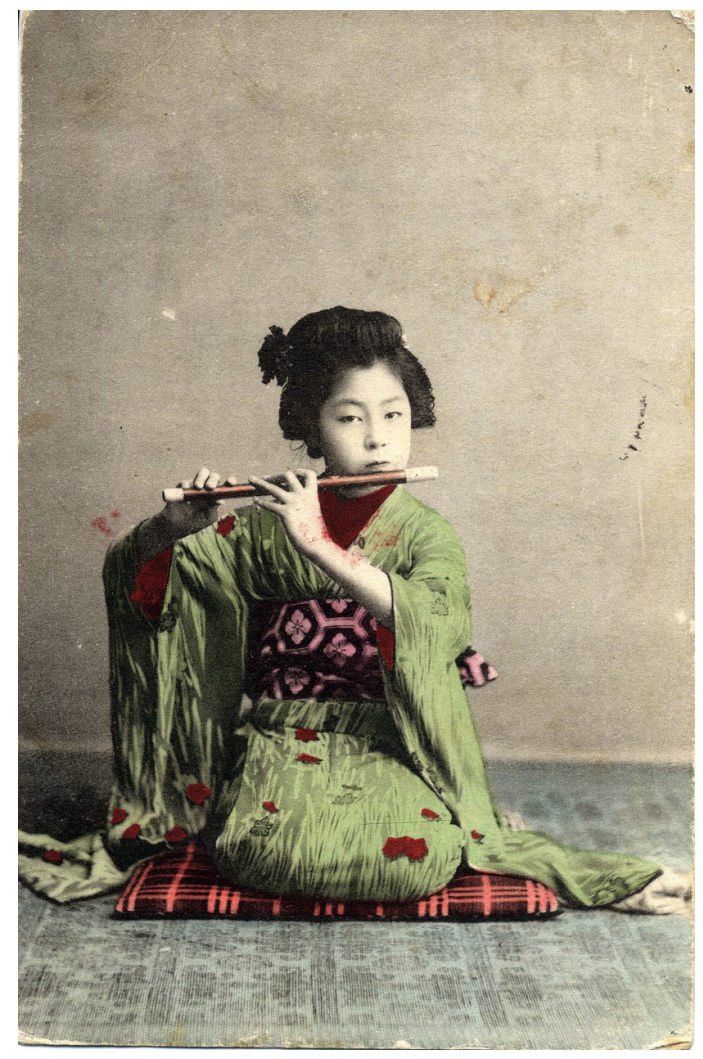

Slika 6: Dekle igra na piščal (Koršičeva zbirka, Pomorski muzej v Piranu)

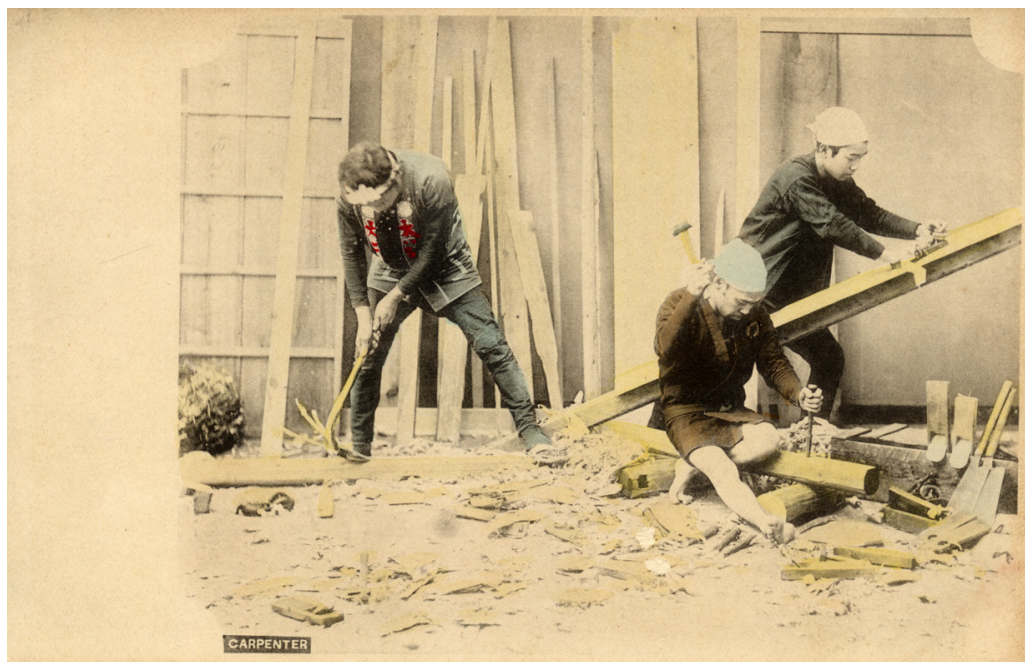

Slika 7: CARPENTERS (Koršičeva zbirka, Pomorski muzej v Piranu) 
Izmed osemindvajset japonskih razglednic v Koršičevi zbirki jih je deset, na katerih je tudi besedilo oz. korespondenca. $\mathrm{Na}$ nekaterih vidimo tudi poštne žige in sledi poštnih znamk, ki so bile odstranjene. Tako vemo, da je bila vsaj polovica teh japonskih razglednic dejansko uporabljena oz. odposlana iz pristanišč na Japonskem ali nekje v Vzhodni Aziji. V tej zbirki večkrat vidimo podpis iste osebe, Zvonimirja Ožegovića. Po arhiviranih podatkih v Pomorskem muzeju je bil Ožegović rojen leta 1885 in delal kot vodja stroja 1. reda (podčastnik). Pogosto je pisal Koršiču: leta 1904 iz Kōbeja, 1905 iz Kōbeja in Jokohame, 1907 zopet iz Jokohame in 1908 iz Kōbeja in Nagasakija. Vsakič je dopisal nekaj besedila in se podpisal zraven fotografije (če je bilo prostora za besedilo) ali tudi čez fotografijo. Njegovo besedilo je vedno v nemščini. Obstaja tudi podpis Alojza Tepine, za katerega vemo, da je bil na križarki Kaiserin Elizabeth: leta 1910 je poslal razglednico iz Jokohame. ${ }^{7}$

\section{Kristanova zbirka}

Pomorski muzej Sergeja Mašere je junija leta 2014 pridobil nove albume Viktorja Kristana. $\mathrm{V}$ dveh med njimi lahko vidimo razglednice in fotografije iz Japonske in sosednih držav. Kristan se je rodil v Šentvidu pri Stični in je bil intendantski častnik na križarki Leopold. Na poti je zbral tri albume fotografij. Na platnici vidimo datuma odhoda in vrnitve križarke: S. M. S. Leopard, 15. IV. 1907-18. IV. 1909.

Med vsemi zbirkami, ki sem jih obravnavala v tej raziskavi, ima Kristanova zbirka največ razglednic z Japonske, kar enainšestdeset. Po vsebini jih lahko razdelimo na tri skupine.

Največja skupina razglednic prikazuje japonska mesta, svetišča in templje. Te fotografije so črno-bele, a so dodatno obarvane, natisnjene po celi površini razglednice in imajo kratko razlago (ponavadi krajevno ime ali naziv svetišča) v japonščini in angleščini. Poleg že zgoraj omenjenih znanih pristanišč so na njih še mesta Shimonoseki, Moji, Kagoshima in svetišča v teh mestih, park in gostišče v Itsukushimi, grad v Nagoyi, Hotel Monju pri znamenitem kraju Ama no hashidate, pogled na goro Fudži z različnih strani, cesarjeva palača v Tokiu idr.

Druga skupina razglednic v Kristanovi zbirki prikazuje življenje, navade in poklice takratnih Japoncev. Tudi te razglednice so prvotno črno-bele s kasnejšim barvanjem, nimajo pa pripisa oz. razlage. Ženski v kimonu, ki se priklanjata pred hišnimi vrati, skupina ljudi na čolnih v ribniku na japonskem vrtu, moški na vrtu perunik, okras pred hišo za praznik dečkov idr.

$7 \quad$ Za podatke o zbiralcih in pomorščakih v zvezi z razglednicami v Pomorskem muzeju Sergeja Mašere v Piranu se zahvaljujem kustosinji g. Marinac. 


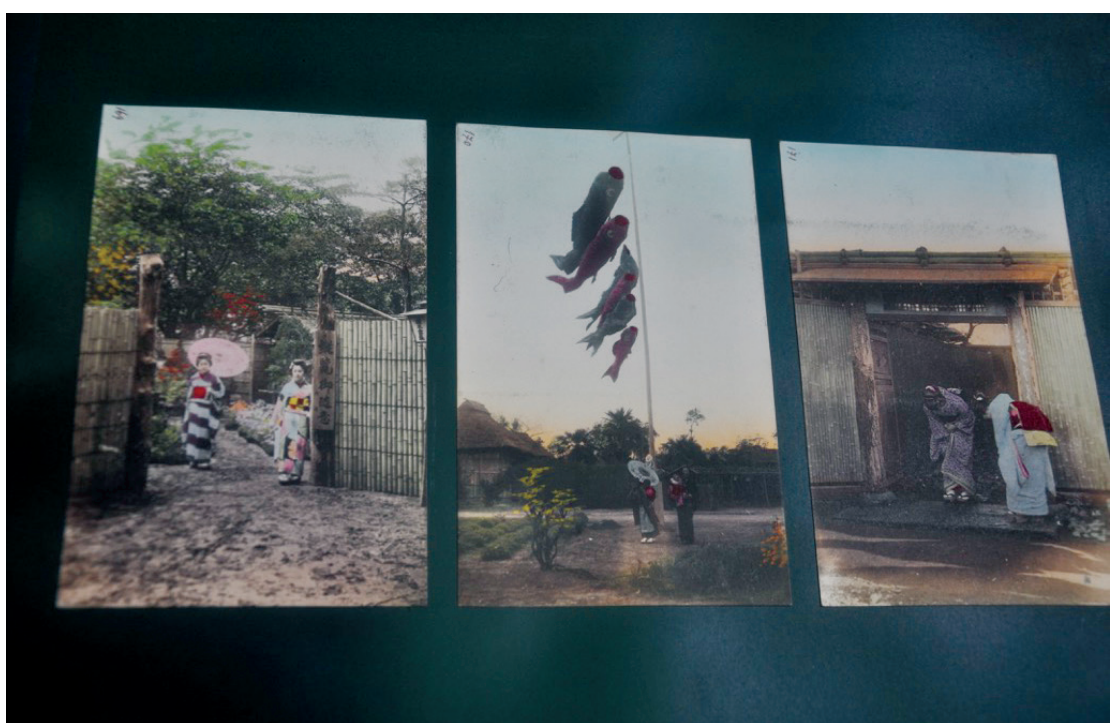

Slika 8: Kristanov album (Pomorski muzej v Piranu)

V zbirki pa so tudi razglednice, ki predstavljajo japonsko življenje znotraj hiše, npr. tri dekleta, ki skupaj prebirajo časopis. Med njimi so tudi trije nepobarvani črno-beli posnetki lutk, ki so oblečene $\mathrm{v}$ japonske zgodovinske noše: po napisih vidimo, da so to dvorne dame, fevdalni gospod in žena fevdalnega gospoda $\mathrm{v}$ obdobju Tokugawa. Ti napisi so samo v japonščini, napisani $z$ desne proti levi po takratnem pravopisu.

$\mathrm{V}$ tretji skupini so razglednice, na katerih vidimo vojne ladje in pristanišča ter bojišča na takratnem japonskem ozemlju na korejskem polotoku in v Mandžurji. Zanimive so razglednice z napisom »Russian Cruiser Variag off Chemulpo«, "Exprosion of the Corietz ${ }^{8}$ in "The Corietz and a Transporter«. Najverjetneje so to fotografije, ki jih je posnel novinar na japonskih vojnih ladjah. So črno-bele in pripis na vsaki od teh razglednic je $\mathrm{v}$ angleščini in japonščini.

Kot sem že omenila, je bil Kristan od druge polovice leta 1907 do prve polovice 1909 na križarki Leopard, kar pomeni, da je nekaj let po končanem rusko-japonski vojni potoval po vzhodnoazijskih pristaniščih. Vidimo, da je bilo možno dobiti take posnetke $\mathrm{v}$ obliki razglednic $\mathrm{v}$ tem času.

V Kristanovi zbirki, pa tudi v Blaznikovi, je kar nekaj razglednic, ki prikazujejo ljudi in navade $\mathrm{v}$ Koreji in na Tajvanu, a jih v tokratno raziskavo nisem vključila. Upam, da bodo kmalu pravilno identificirane in uvrščene v ustrezni obliki.

$8 \quad$ S tipično japonsko napako v črkovanju (explosion/exprosion). 


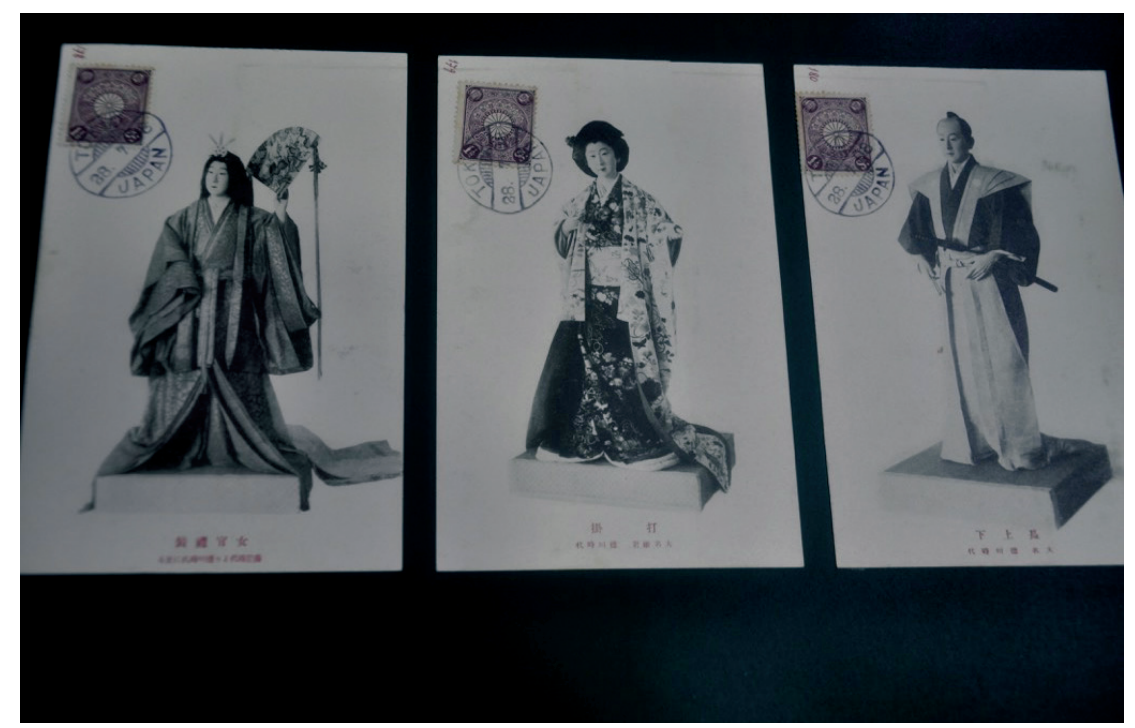

Slika 9: Oblačila iz obdobja Tokugawa (Kristanova zbirka, Pomorski muzej v Piranu)

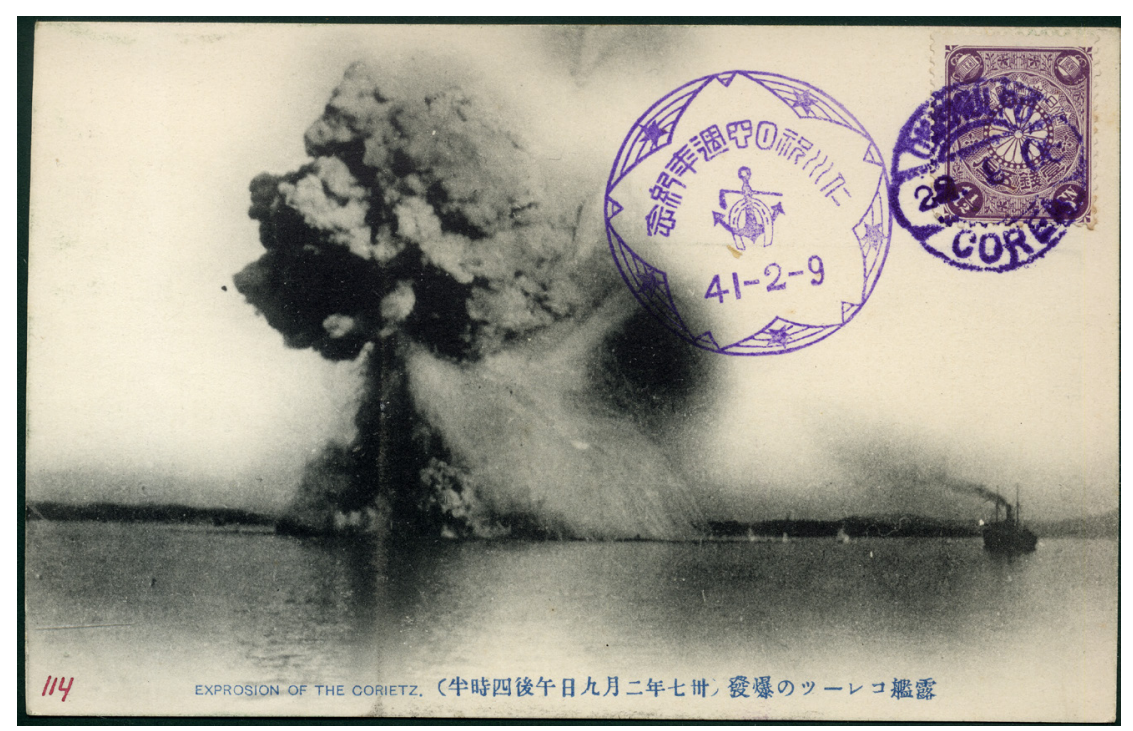

Slika 10: Eksplozija ruske vojne ladje Corietz (Kristanova zbirka, Pomorski muzej v Piranu) 


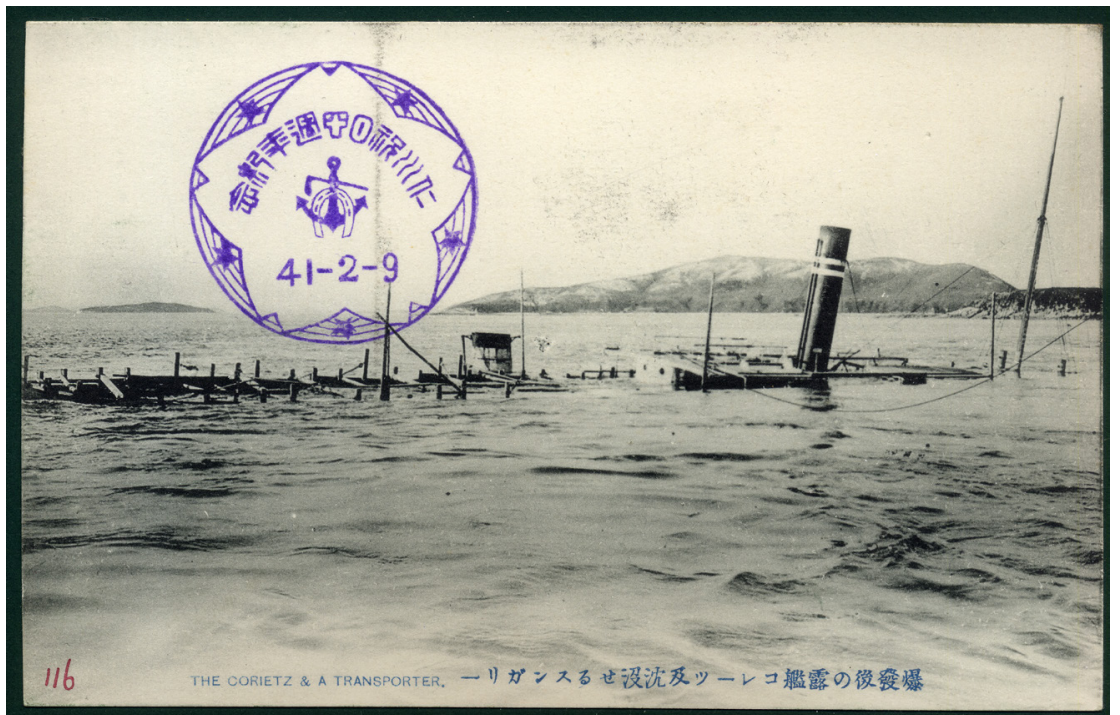

Slika 11: Corietz in Sungari (Kristanova zbirka, Pomorski muzej v Piranu)

\section{Blaznikova zbirka}

V Pomorskem muzeju Sergeja Mašere v Piranu je tudi album Avgusta Blaznika. Blaznik je bil rojen v Fari pri Kostelu na Kočevskem in je končal podoficirsko artilerijsko šolo v Šibeniku. Do leta 1918 je delal na različnih ladjah. Njegova zbirka je ohranjena tudi $\mathrm{v}$ albumu, na njegovi sprednji platnici vidimo naslov »BLASNIK A. 1905-1913«. Tematika njegovega zbiranja je bila nedvomno vojna ladja, vendar med razglednicami in fotografijami ladij najdemo tudi pokrajine, znamenitosti raznih krajev, pristanišča ipd. Japonskih razglednic je v tem albumu šestnajst in vidimo lahko podobnosti s Kristanovo zbirko: čeprav so razglednice $z$ Japonske maloštevilne, so vseh treh vrst: pokrajina in mestni prizori, navade in poklici ter vojne ladje. Najbolj zanimivo pri tem albumu je, da vidimo razglednice vojnih ladij iz časa Japonskega imperija. Ohranjene so razglednice križark Mogami, Izumo in Takachiho.

$\mathrm{V}$ Blaznikovem albumu je kar nekaj fotografij in razglednic, ki prikazujejo pokrajino takratnega japonskega ozemlja na celini (npr. mesto Dalian/Dairen, koncesija pri Inchonu, bojišča pri pristanišču Ryojun - Port Arthur, bojišče Shōjusan). Vse te razglednice (in fotografije) so črno-bele. 


\section{Štibilova zbirka}

Pomorski muzej Sergeja Mašere hrani tudi predmete, ki so bili v lasti Matevža Štibila, rojenega leta 1890 v Struženem pri Kranju. Postal je inštruktor topništva v avstro-ogrski mornarici in služboval na ladjah Tegetthoff, Maria Theresia in Prinz Eugen. V njegovi zbirki so tri japonske razglednice, ki so mu jih verjetno njegovi učenci poslali iz kitajskih pristanišč. Na eni od teh razglednic je razvidno, da je bila oddana v Tjanjinu 9. februarja 1912. Na naslovu se vidi, da je bil naslovnik Štibil z ladjo Maria Theresia enkrat v pristanišču Trst, drugič pa v Pulju. Tretja razglednica je poslana na ladjo Tegetthoff $v$ pristanišču Pulj. Naslovi so napisani v nemščini in italjanščini, besedilo dopisovanja pa je slovensko.

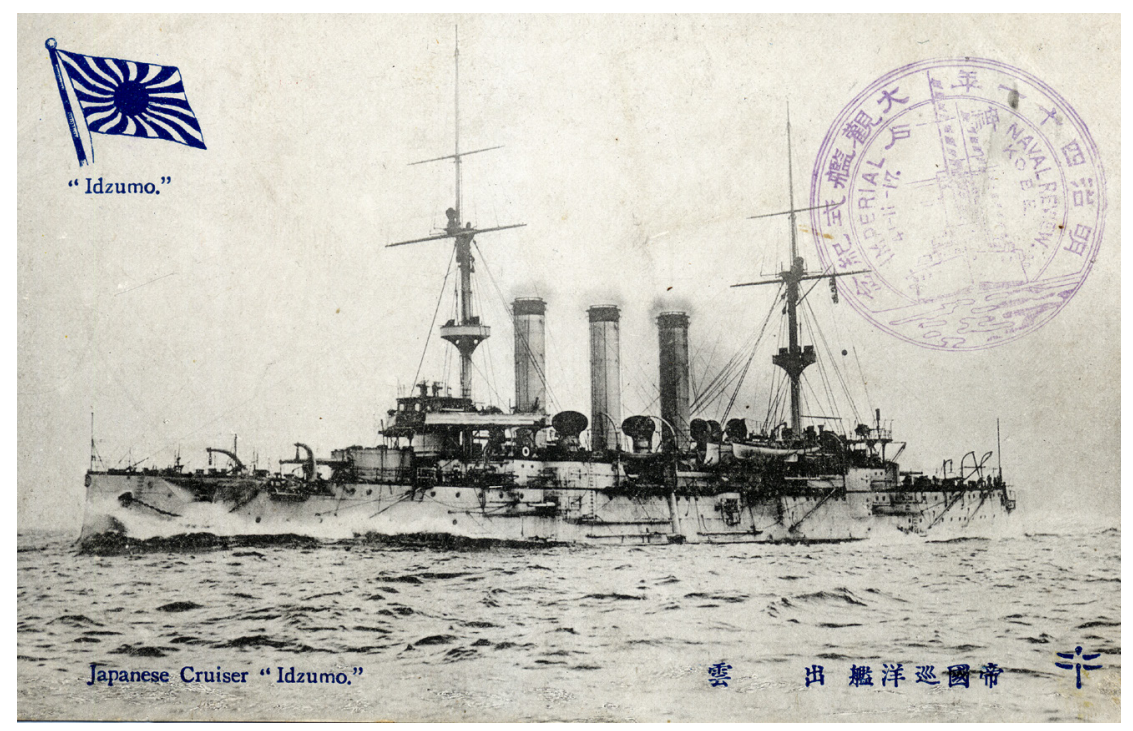

Slika 12: Japonska križarka Izumo (Blaznikova zbirka, Pomorski muzej v Piranu)

Motivi teh razglednic so mlada Japonka v prazničnem kimonu $\mathrm{z}$ japonsko pričesko (črno-bela fotografija brez napisa); dekleti v takratnih kopalkah z rokavi in do kolen, ki ležita na pesku (črno-bela fotografija z dodanimi barvami) in narisana obmorska pokrajina s kočo, borom in pticami. Polovica hrbtne (naslovne) strani prvih dveh razglednic je namenjena za besedilo. Tretja razglednica ima tudi del za korespondenco in $\mathrm{v}$ sredini naslovne strani vidimo napis MADE IN JAPAN. 


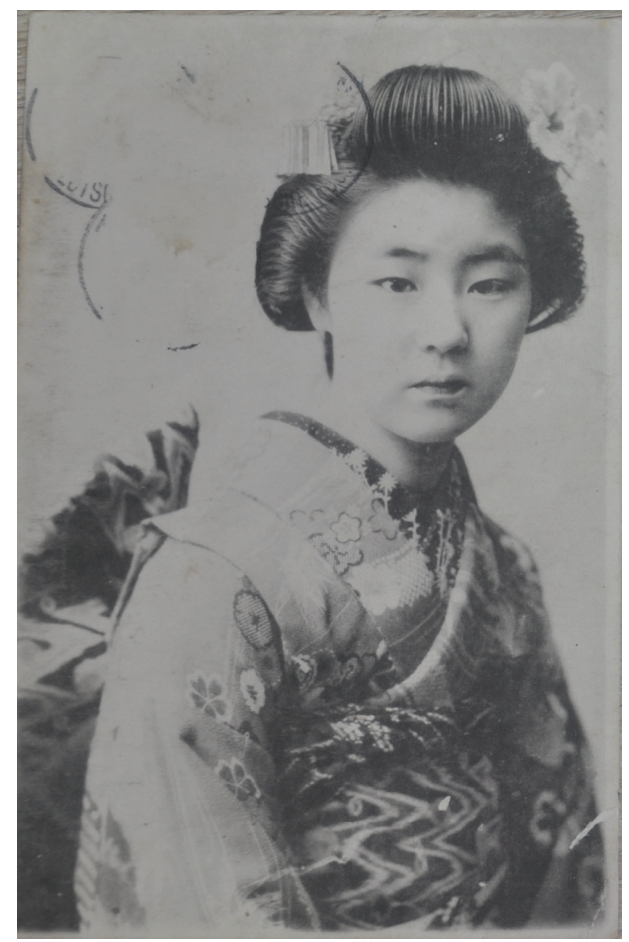

Slika 13: Mlada Japonka v prazničnem kimonu z japonsko pričesko (Štibilova zbirka, Pomorski muzej v Piranu)

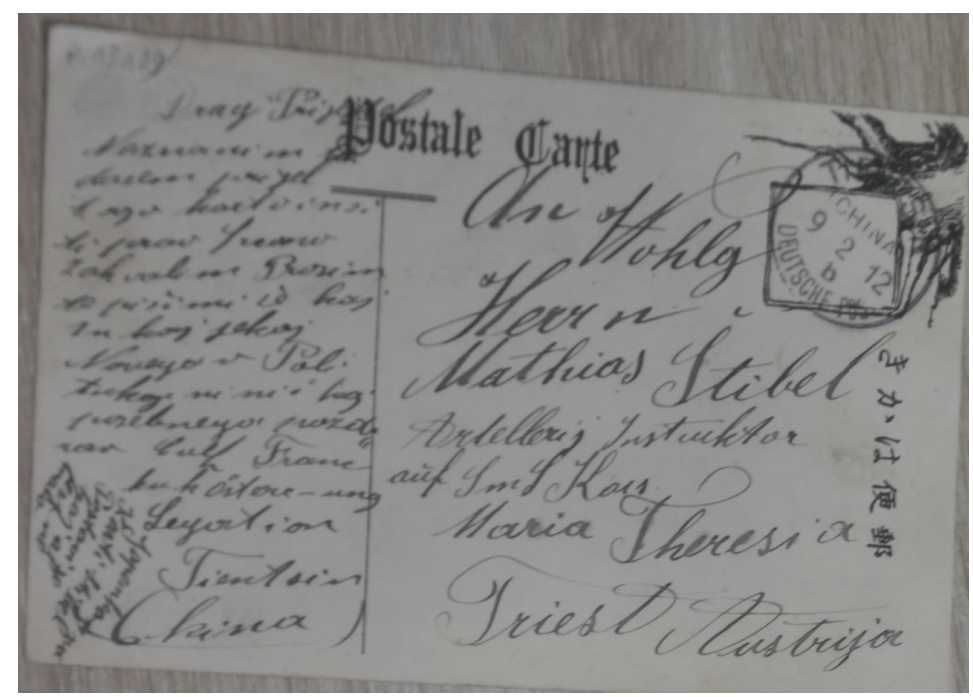

Slika 14: Hrbtna stran razglednice Slike 13 (Štibilova zbirka, Pomorski muzej v Piranu) 


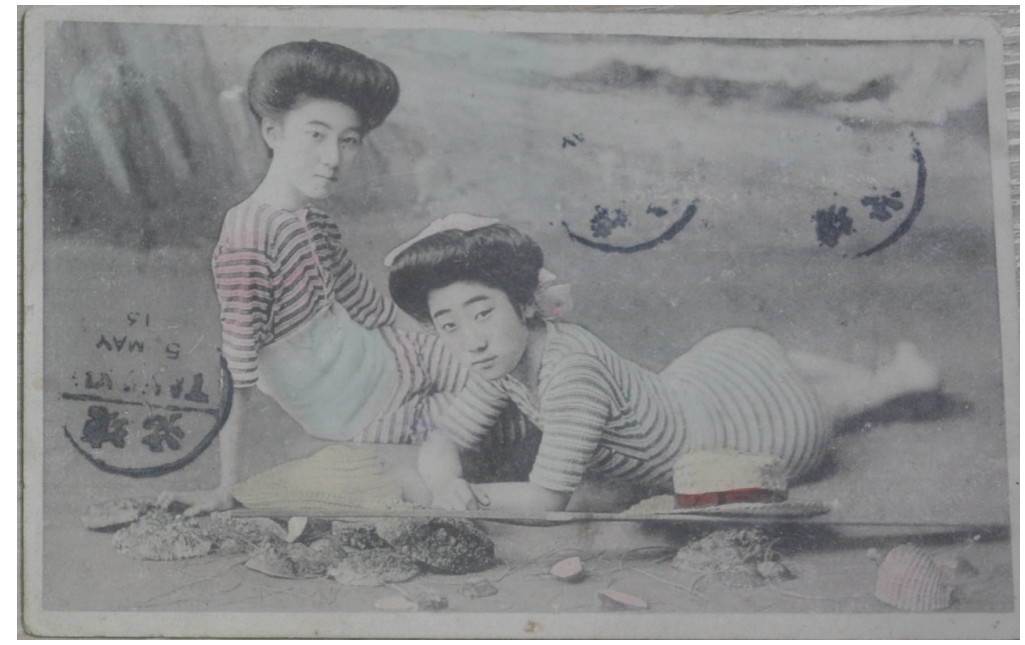

Slika 15: Dekleti v kopalkah (Štibilova zbirka, Pomorski muzej v Piranu)

\section{Pokrajinski muzej v Celju}

Pokrajinski muzej Celje hrani obsežno zbirko predmetov, ki jih je zbrala Alma Maksimilijana Karlin na potovanju okoli sveta med letoma 1919 in 1928. Med njenimi razglednicami so tudi japonske, ki prikazujejo Japonsko v obdobju Taishō. To so nekoliko novejše razglednice v primerjavi s tistimi, ki jih hranijo v NUK-u, Biblioteki SAZU in v Pomorskem muzeju Sergeja Mašere v Piranu.

Alma Karlin se je rodila leta 1889 v Celju (Cilli). Starši so bili Slovenci, a so za vzgojo Alme uporabljali izključno nemški jezik. Kasneje je kot novinarka in pisateljica pisala v nemškem jeziku. Kot mlado dekle se je v Londonu, Oslu in Stockholmu naučila številnih jezikov, ki jih je poučevala v domačem Celju. Leta 1919 je šla na potovanje okoli sveta in preko Peruja ter Havajijev junija 1922 prispela na Japonsko. Malo več kot eno leto je ostala na Japonskem, v glavnem v Tokiu, in nato nadaljevala pot na Korejo, Kitajsko, Polinezijo itd. V Slovenijo se je vrnila leta 1927. Z Japonske je poleg razglednic prinesla fotografije, ki jih je vsaj del posnela sama, drobne vsakdanje predmete in turistične spominke ter oblačila (yukata idr.). O svojem potovanju je pisala članke in jih pošiljala v nemške in angleške časopisne hiše. $\mathrm{Na}$ osnovi njenega pisanja in predmetov v zbirki lahko rekonstruiramo precejšnji del njenega potovanja okrog sveta (Stanonik 1983; Trnovec 2011).

Večina razglednic, ki jih je Alma Karlin poslala svoji materi in prijateljicam v Celju, prinesla domov ali pa s potovanja poslala domov z drugimi predmeti, je danes ohranjena v Pokrajinskem muzeju v Celju. Med njimi jih je 36 z Japonske. Številčno jih ni veliko, vendar je ta zbirka v primerjavi s prejšnjimi zbirkami bolj 
raznolika. Alma Karlin je živela na Japonskem leto dni in nekaj časa delala za nemško veleposlaništvo. To pomeni, da je bila v stiku z Japonci in tujci, ki so takrat živeli na Japonskem, in ti so jo morda peljali na različne japonske kraje, ali pa je sama obiskala kraje, za katere je slišala, da so zanimivi. Tudi časovno je ta zbirka več kot osem let mlajša od drugih, kar pomeni, da so razglednice tudi novejše in z več novimi idejami pri oblikovanju. Med tem časom je cesar Meiji umrl in Japonska je začela novo obdobje, Taishō.

Največ razglednic v zbirki Alme Karlin prikazuje svetišče Meiji v Tokiu. Med njimi so: narisana skica celotnega svetišča, črno-bele fotografije posameznih zgradb ali vrat, ki so opremljene $\mathrm{z}$ razlago $\mathrm{v}$ japonščini. Posebno zanimiva je razglednica, ki nam kaže, da je bilo obdobja Meiji že konec, črno-bela fotografija treh lutk, ki so jih takrat postavili v nekdanji hiši generala Nogi iz rusko-japonske vojne.

$\mathrm{V}$ tej zbirki vidimo tudi pokrajinske in turistične razglednice, ki predstavljajo Tokio (park v Asakusi; svetišče v Kandi; rdeča vrata Tokijske cesarske univerze; zadnji dve sta narisani in imata japonski napis), Beppu, Ashikaga, Kjoto, Nara (templja Daian-ji in Hōryūji), Itsukushima, Kamakura, lokalni praznik v Akiti, gore Sagami Ōyama, Tochigi Taihei-san idr. Ravno v času, ko je Alma Karlin prispela na Japonsko, so v predelu Ueno v Tokiu prirejali Razstavo miru (The Tokyo Peace Exhibition 平和 記念東京博覧会). Najbolj verjetno je šla na razstavo, ker je od tam tudi razglednica lutke “ples” kiparja Nakatanija Gankoja (中谷習古 1868-1937).

$V$ tej zbirki sem našla tudi šest razglednic novega tipa. To so posnetki naravne katastrofe na Japonskem. Dve prikazujeta prizora v starem predelu Tokia (Minami senju in Mukōjima) takoj po veliki poplavi avgusta 1910, ostale štiri pa kažejo škodo, ki jo je v starem predelu Tokia (Aioi-bashi, Fukagawa, Etchūjima, Suzugamori) julija 1911 povzročil cunami. Vidimo, da so prebivalci v času poplave v čolnih veslali po mestu. Po cunamiju pa so naredili posnetke lesene barke in torpedovke, ki ju je naplavilo na kopno. Vsi posnetki so črno-beli in pod vsakim posnetkom je kratka razlaga $v$ japonščini, natisnjena $\mathrm{z}$ desne proti levi. Originalni napisi so v Tabeli 3.

\begin{tabular}{|c|l|}
\hline \multicolumn{2}{|c|}{ Besedilo pod posamezno fotografijo } \\
\hline 1 & $\begin{array}{l}\text { 明治四十三年八月都下稀有ノ大洪水 向島牛ノ御前ノ浸水 } \\
\text { (velika poplava avgusta 1910, Mukōjima Ushi no gozen) }\end{array}$ \\
\hline 2 & $\begin{array}{l}\text { 明治四十三年八月大洪水惨況（南千住天王前） } \\
\text { (velika poplava avgusta 1910, Minami senju tennō-mae) }\end{array}$ \\
\hline 3 & $\begin{array}{l}\text { 明治四十四年七月廿六日午前二時海嘯ノ襲来 } \\
\text { 部洗イ受タル相生橋中島ノ橋畔一 } \\
\text { (Po cunamiju ob dveh zjutraj 26. julija 1911, Aioibashi Nakashima) }\end{array}$ \\
\hline
\end{tabular}




\section{Besedilo pod posamezno fotografijo}

4 明治四十四年七月廿六日午前二時海嘯ノ為入達磨船深川黒船橋通りエ吹上 ゲラル

(Po cunamiju ob dveh zjutraj 26. julija 1911, lesena barka na cesti Kurofunebashi dōri, Fukagawa)

5 明治四十四年七月廿六日拂暁ノ椿事（つなみ）水雷艇越中島陸上二打上ラル (Cunami zgodaj zjutraj 26. julija 1911, torpedovka na Etchûjimi)

6 明治四十四年七月廿六日拂暁ノ椿事（つなみ）鈴ヶ森附近ノ惨状 (Cunami zgodaj zjutraj 26. julija 1911, Suzugamori in okolica)

Tabela 3: Napisi na fotografijab naravnib katastrof v zbirki Alme Karlin

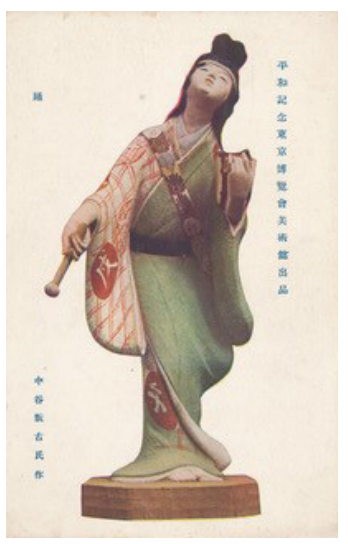

Slika 16: Lutka "Ples" kiparja Naktanija Gankoja (Zbirka Alme Karlin, Pokrajinski muzej v Celju)

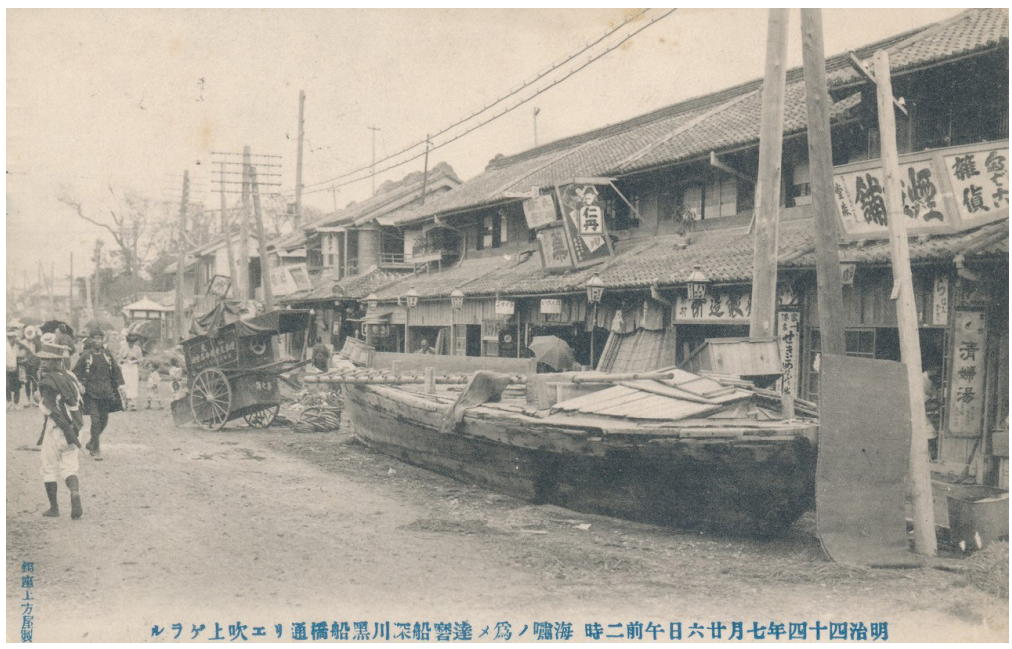

Slika 17: Po cunamiju ob 2:00. 26. julija 1911: lesena barka na cesti Kurofunebashi döri, Fukagawa (Zbirka Alme Karlin, Pokrajinski muzej v Celju) 


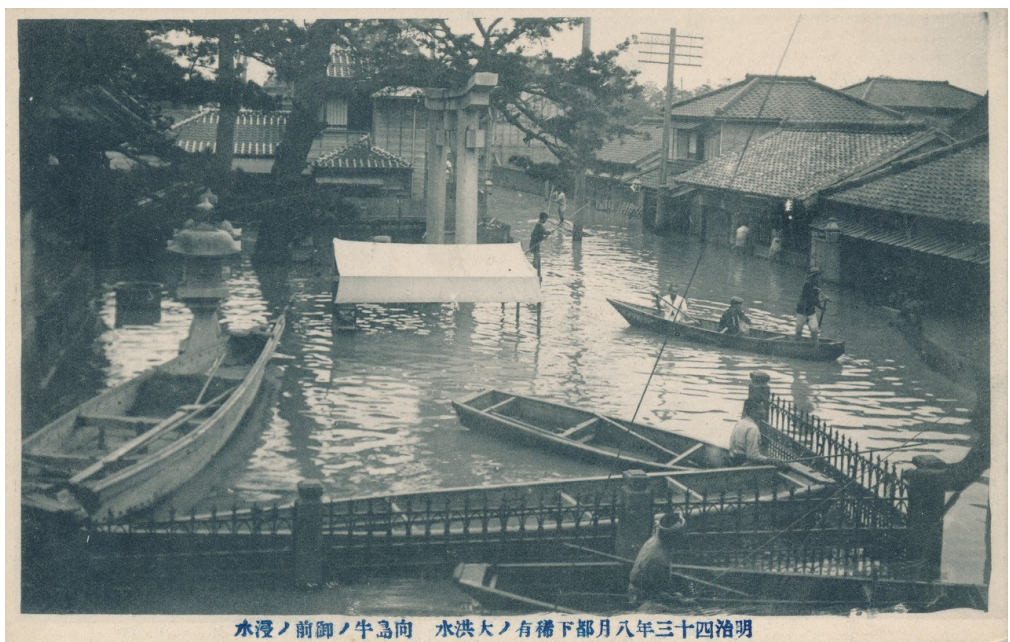

Slika 18: Velika poplava avgusta 1910, Mukōjima Ushi no gozen (Zbirka Alme Karlin, Pokrajinski muzej v Celju)

Tretja razglednica v tabeli, most Aioibashi, je bila tudi uporabljena: naslovljena je na Almo Karlin na njenem celjskem naslovu, nalepljena je angleška poštna znamka za en peni ${ }^{9}$. $\mathrm{Na}$ tretjini hrbtne strani, namenjeni korespondenci, piše: "Tu je šest kartic, ki prikazujejo škodo zaradi (japonskega) cunamija v predmestju Tokia, 26. julija lani. N. G.”. ${ }^{10} \mathrm{Na}$ koncu naslova pa piše Avstrija, kar pomeni, da te razglednice ni dobila med svojim potovanjem okoli sveta, ampak pred odhodom, ko je bila še v Celju, od znanca v Angliji. Ne glede na to, kako je razglednica prišla $\mathrm{v}$ Almino last, vidimo, da so imele japonske razglednice proti koncu obdobja Meiji funkcijo posredovanja novic.

Med razglednicami v zbirki Alme Karlin so tudi take, ki predstavljajo pokrajino in navade takratne Koreje in Tajvana. 11 korejskih razglednic skupaj z 39 fotografijami iz Koreje v Alminini zbirki sem podrobno obravnavala leta 2012 v članku v angleščini. ${ }^{11}$ Razglednice s Tajvana v zbirki pa še čakajo na obdelavo.

9 Rdeča znamka z obrazom kralja Jurija V., ki so jo uporabljali okoli 1911-1912.

10 These six cards are the photos of the damage caused by the tsunami (Japanese) in skirt of Tokyo, on the 26th July last. N.G.

11 "Koreans and citizens of the Habsburg monarchy or its successor-states: early individual encounters (until 1950)” na Koreanistiki Dunajske univerze, 30.-31. januarja 2012

Chikako Shigemori Bučar: "A Slovenian woman in Korea: Alma Karlin's observations”, Koreans and Danubians - Early informal contacts, Praesens, Vienna. 


\section{Doba razglednic in funkcija razglednic}

Večina starih razglednic, ki sem jih analizirala v tem prispevku, je bila oblikovana za tuje, zlasti zahodne obiskovalce Japonske. Najbolj pogosti motivi so bili mesta in zgodovinske znamenitosti, prizori iz vsakdanjega življenja takratnih Japoncev (hiše, vrtovi, stanovanja, pričeske, oblačila), vrste poklicev in prazniki. Podobne razglednice najdemo tudi danes, čeprav so se tudi druga komunikacijska sredstva precej razvila. Morda je danes manj razglednic, ki prikazujejo oblačila in poklice, ker je zaradi globalizacije vedno manj razlik med navadami in življenjem ljudi različnih kultur.

V zbirki Viktorja Kristana v Pomorskem muzeju sta bili razglednici, na katerih smo videli eksplozijo ruske vojne ladje in potop ruske križarke Varjag. V Celju sem v zbirki Alme Karlin našla razglednice, na katerih so bili posnetki takoj po naravnih nesrečah, po poplavi avgusta 1910 in neurju 26. julija 1911. Te razglednice so igrale vlogo današnjega časopisa oz. radia in televizije, ki posredujejo trenutne dogodke in poročajo o nesrečah. Namesto da bi objavljali fotografije o dogodkih v časopisju, so jih oblikovali v razglednice, podobne tistim iz znamenitih krajev, in jih skušali na isti način prodajati tujim obiskovalcem. Na začetku dvajsetega stoletja so $\mathrm{v}$ Evropi še vedno samo nekateri posamezniki dobivali tuje revije in časopise, verjetno $z$ zamudo. $V$ tem času pa se je poštni sistem po vsem svetu hitro razvijal in tudi Slovenija, ki je bila del takratne Avstro-Ogrske, se je povezovala $\mathrm{z}$ Japonsko, ki v obdobju Meiji hitro urejala poštni sistem po zahodnem vzorcu. V prvi polovici dvajsetega stoletja, ko še ni bilo televizije, so te razglednice s fotografijami, ki so posredovale novice o dogodkih, najbrž precej vplivale na prebivalce manjših evropskih krajev. Lahko rečemo, da so bile razglednice, skupaj s poštnim sistemom, pomemben medij, s pomočjo katerega so ljudje lahko izvedeli za dogodke v oddaljenih krajih.

V kontekstu tokratne raziskave lahko rečem, da je bilo obdobje od konca devetnajstega stoletja do prve polovice dvajsetega stoletja za Slovence »doba razglednic«.

\section{Sklep}

Predvidevam, da je v Sloveniji še več ustanov, ki hranijo stare japonske razglednice. To so pokrajinski muzeji in knjižnice, ki jih sodelavci Oddelka za azijske študije še nismo obiskali. Morda obstajajo tudi zasebne zbirke. V tem članku sem obravnavala zbirke samo do leta 1923, vendar je velika možnost, da obstajajo tudi zbirke razglednic iz kasnejših let, tridesetih in štiridesetih let dvajsetega stoletja. Funkcija novejših razglednic je verjetno drugačna. V primeru Slovenije, 
ki je bila po drugi svetovni vojni del Socialistične federativne republike Jugoslavije, je bilo razmerje med razglednicami in komunikacijo po radiu in televiziji morda drugačno kot $\mathrm{v}$ zahodnih državah. Tudi po številu turistov in poznejšem razvoju poštnega in telefonskega sistema v novejšem času bi verjetno našli posebnosti.

Zanimiva je tudi povezava med razvojem fotografske tehnike in razglednicami na Japonskem od obdobja Edo dalje v Meiji. Saitō (2004) na primer piše, da so najprej tuji fotografi iz zahoda fotografirali japonske pokrajine in ljudi, nato so se posamezni Japonci naučili fotografiranja in počasi v pristaniščih in večjih mestih odprli svoje fotografske studie.

V zbirkah v Pomorskem muzeju vidimo več primerov, pri katerih so razglednice in fotografije mešano spravljene $\mathrm{v}$ albumih. Za fotografije pa večkrat ne vemo, ali so jih posneli posamezni zbiralci oz. potniki ali pa so jih na potovanju kupili. V nadaljnem raziskovanju se bom posvetila tudi razliki med komercialnimi razglednicami in fotografijami ter zasebnimi fotografskimi posnetki.

\section{Viri in literatura}

Čeplak Mencin, Ralf. 2012. V deželi nebesnega zmaja: 350 let stikov s Kitajsko. Ljubljana: Založba *cf.

Barclay, Paul. 2014. "How to Ascertain the Date (or Time Period) of Prewar Japanese Picture Postcards.” East Asia Image Collection Blog, Lafayette College, Easton, Pennsylvania. Dostop 15.3.2017. http://sites. lafayette.edu/eastasia/2014/09/04/how-to-ascertain-the-date-or-timeperiod-of-a-japanese-postcard/.

Marinac, Bogdana. 2005. "The Memories of the Journey of the His Majesty Ship Saida: The Austro-Hungarian Military Navy Ship Journeys as Seen through the Eyes of Slovenian Seamen." Museo del Mare 'Sergej Mašera' Piran (muzejski letak).

Pajsar, Breda. 2008. "Knjižnica Ivana Jagra v fondu Bibilioteke SAZU.”V Sedemdeset let Biblioteke Slovenske akademije znanosti in umetnosti. Ljubljana: SAZU. Park, Mijeong. 2014 Teikoku shihai to chösen hyōshö, Nichibunken sōsho 52. Kyoto: Nichibunken.

Podberšič, Renato. 2010. "Ivan Koršič.”V Tvorci slovenske pomorske identitete. Življenje in dela VI, Biografske in bibliografske študije 4, uredil Andrej Rahten, 137-47. Ljubljana: Založba ZRC.

Pomorski muzej v Piranu (b.n.l.) Slovene Seamen in The Austro-Hungarian Navy (letak). 
Rothaus, Richard. 2013. "John Jager: Unknowm Prairie Architect in Minnesota. Part1.” SAH Blog. Dostop 25.8.2016. http://www.sah.org/publications-and-research/sah-blog/sah-blog/2013/05/15/john-jager-unknownprairie-architect-in-minnesota.-part-1.

Saitō, Takio 斎藤多喜夫. 2004. Bakumatsu Meiji Yokohama shashinkan monogatari Rekishi bunka raiburarii 175 『幕末明治横浜写真館物語』歴史文化ライ ブラリー175. Tokyo: Yoshikawa Kōbunkan吉川弘文館.

Shigemori, Chikako. 2016. "Surovenia kyōwakoku hokan no ehagaki korekushon 「スロヴェニア共和国保管の絵葉書コレクション」.”V Nibon teikoku no byōshō: seisei, kioku, keishō 『日本帝国の表象 生成・記憶・継承』 (Izrazi Japonskega imperija: nastanki, spomini in dedišcina), uredila Park Mijeoung 朴美貞 in Rei Hasegawa 長谷川怜, 219-44. Tokyo: Enishi shobō.

Stanonik, Janez. 1983. “Alma Maximiliana Karlin.” Australian Papers, 41-48.

Trnovec, Barbara. 2011. Kolumbova bči: življenje in delo Alme M. Karlin (Columbus's Daughter: Life and Work of Alma M. Karlin). Celje: Pokrajinski muzej. Zgodovina NUK. 2016. Dostop 25.8.2016. http://www.nuk.uni-lj.si/nuk/ zgodovina-nuk. 